PROJECT MANAGEMENT IN

PUBLIC ADMINISTRATION. TPM -

TOTAL PROJECT MANAGEMENT

MATURITY MODEL.

THE CASE OF SLOVENIAN

PUBLIC ADMINISTRATION

\section{Gordana ŽURGA}

\author{
Gordana ŽURGA \\ Associate Professor, \\ Faculty of Organisation Studies, Novo Mesto, Slovenia \\ Tel.: 0386-40-228.040 \\ E-mail: gordana.zurga@fos.unm.si
}

\section{Abstract}

The purpose of the article is to present the importance of project management for the functioning of public administration, and its contribution to the realization of the developmental goals of the government. For this, integration of strategic management and project management is of vital importance. The methodology used is a combination of literature review, a case study of project management in public administration of the Republic of Slovenia, and development of a maturity model of project management in public administration, with its verification on the case of Slovenia.

The main contribution of the study is development of TPM - Total Project Management maturity model for public administration. Upon the TPM maturity model, project management in Slovene public administration is assessed and discussed. Out of five maturity levels, the results for project management in Slovene public administration are: management of projects - level 2 (initiated), management of programs of projects - level 2 (initiated), management of portfolios of projects - level 3 (implemented), organizational support for project management - level 3 (implemented), HRM for project management - level 2 (initiated), and integration of project management and strategic management - level 3 (implemented). General findings and recommendations in this respect are drawn, together with indicated areas for possible further research and investigation.

Keywords: project management, public administration, public management, strategic management, project management office, project management maturity, TPM maturity model, Slovenia. 


\section{Introduction}

Public administrations (PA) in all countries face increasing demands for higher effectiveness, efficiency and quality of services. Development of PAs goes into the direction of establishing managerial principles and public governance, increasing their efficiency and quality, trying to achieve and maintain the sustainability of their functioning.

Changes of these kind demand strategic approach, clear definition of PA roles and functions, and implementation of new principles and ways of functioning. To achieve best possible results, the whole change process has to be carefully and systematically planned and managed. After the definition of strategic areas and strategic goals, appropriate strategies have to be developed and operationalized. For this, several conditions and frameworks are to be fulfilled - among others, also the integration of strategic and project management as strategies are being implemented through projects, or programs of projects. Several authors recognize the high priority of strategic planning for successful project management (Rozman, 2000; Žurga, 2004; Kerzner, 2001; Young et al., 2012).

We consider project management (PM) as an important part of public management especially because of implementation of developmental goals of states and their administrations, and continual improvement of the quality of PA's functioning and services. As we talk here about changing public administration, PM is not only part of public management, but is also very strongly connected to change management and quality management in PA.

In practice, we still too often encounter the traditional view of PA organizations that sees individual PA organizations predominantly as structures. In connection with the lack of managerial culture, this view is quite logical. However, there are consequences of such understanding of PAs as reforms are then seen basically as changes in structures. In functioning of the contemporary PAs, individual PA organizations are more and more seen and understood as sets of strategies rather than sets of structures. This understanding consequently changes the starting point for strategies' development. One of the important questions in this respect is which are the levers to be used to realize real changes.

When addressing this question we cannot avoid analyzing the role of politicians and political management. We have to be aware that (many of) reforms are in fact programs of projects going far beyond the mandate of one government. Even when a project or a program of projects is concluded within this timeframe, effects are longterm: impacts of a project or program are something that usually the next government benefits from. Yet, developmental programs are usually not limited to or by one mandate of a government. They are or they should be inspired by a vision of a state where political management and governments all play their roles: governments govern to serve, and to enable conditions for better lives of their citizens and prosperity of economies. 
In light of this, strong project management in the executive branch of power is needed for the realization of developmental goals and government strategies and policies.

\section{Project management in public administration - brief theoretical and methodological overview}

Although the discipline of PM itself is quite old, its usage in the context of PA is noted on larger scale in the late 1970s and/or early 1980s. Impressive historical overview on PA development has been done for the occasion of the $50^{\text {th }}$ anniversary of International Association of Schools and Institutes of Administration (IASIA) in 2011 (Dwivedi and William, 2011) that includes also the aspect of project management. According to Collins (2011, p. 85), the role of PM is connected to institutional development in PA in the 1980s which he considers broader than administrative reform. Focus of institutional development is on innovative capacity which requires projects and their effective management; Collins also exposes the increasing role of information technology in this respect. Some authors report on project-related training (Schams apud Collins, 2011), or 'in situ training, with action learning approaches through work related projects' (Clarke apud Collins, 2011).

By spreading the New Public Management (NPM) around the world, PM in PA gained its importance respectively, one could even say exponentially. Several authors classified the NPM era or tried to find some general patterns in approaches. In this respect we mention the classification of NPM models as efficiency assurance, downsizing and decentralization, business excellence, and orientation in public service delivery (Ferlie et al., 1996). All four models include also PM aspect to make new developments happen. The NPM era is strongly characterized also by changing the role of the state and its government from someone who delivers public services to a services' provider (Osborne and Gaebler, 1992; Flynn and Strehl, 1996). In this way, management practices from the private sector were transposed into public sector. Unfortunately, not always with due professional critics and/or focus (Flynn and Strehl, 1996) followed by mixed results. Powell and de Vries (2011, p. 106) even argue 'that the ideas of NPM stayed alive partly because of its critics'. As indicated by Hammerschmid et al. (2016, p. 5), there are nowadays countries where NPM is very much alive and countries that 'have already embraced a variety of post-NPM ideas'.

In respect to the theoretical framework it has to be emphasized that considering $\mathrm{PM}$ as an important part of public management has not been given too much attention. This leads us to a brief methodological overview of the PM area in PA.

Some governments have put their own efforts into controlling the administrative reform change processes, monitoring the success of projects that were contracted out, or in trying to achieve participation and financing of different stakeholders (Collins, 2011, pp. 89-90). Maybe the most known in this respect is the methodology that was developed by the UK government, known under the name PRINCE. As being the most relevant of a kind at that time (late 1980s and early 1990s) it soon was adopted 
by many countries. Also the influence of strong international organizations that financed developments at national level is very important. They developed their own PM methodologies, first to evaluate candidate projects, and then to monitor and control them. However, organizations like the World Bank, the UN, the IMF, the OECD and others by their co-financing and/or expertize do not share only the PM methodology but also the ideas on what should be on governments' agendas (Charniawska and Joerges apud Powell and de Vries, 2011, p. 103).

Undoubtedly, the role of PM in PAs in the EU member states (MS) became more important under the circumstances of implementing projects that are co-financed through EU founds. Every new EU MS tries to benefit from the new partnership as much as possible, including also EU funding of the national developmental projects (Nicolaides, 2003). It is a fact that for many EU MSs - in the times of the last financial and economic crises - this was one of rare sources (or even the only source) to finance the developmental projects. As reported by Kostalova, Tetrevova and Patak (2015, p. 112), 'the system of support for projects co-financed by EU funds applied in the CZ within the $\mathrm{PP}^{1}$ 2007-2013 was, from the point of view of the organizers of these projects, connected with a number of problems'. Problems in respect to the system of support for projects are usually connected to problems at higher level - more or less similar situation could be found also in some other countries indicating the importance for an EU MS to have sound strategic management as well project management. Already in 1989, Youker (1989, p. 55) reported that the most important lesson from (at that time) 40-year experience of the World Bank was 'that countries must actively manage the entire cycle ${ }^{2}$; they should have a standard process that they understand and use'.

For covering project cycle for projects that are co-financed by the EU, the European Commission ${ }^{3}$ adopted in 1992 a common methodology known as PCM - Project Cycle Management. This is a five-phase project life cycle methodology, aiming to 'support good management practices and effective decision making throughout the project management cycle - from programming, through identification, formulation, implementation and evaluation' (European Commission, 2004).

Every EU MS tries to maximize the gain from the EU funds. In preparing, executing and evaluating their projects, states have to follow the prescribed PM methodology. However, states also have to establish a managerial framework for incorporating these projects into the national developmental agenda that is in line with the EU agenda, which is much more as pure PM methodology. It requires sound general and strategic management, and a clear role of political management as well. In this respect, countries do not share the same experience.

1 PP - Programming Period

2 'Cycle' here stands for WB's Project Cycle

3 First PCM manual was produced in 1993, and was updated in 2001. 
It is necessary for states to have strong strategic management, as well as mechanisms for strategic plans implementation - PM is one of them. By using and fostering PM in their PAs governments contribute to a more efficient use of public finances and better public management. These leads us to the research question that we present in the next section.

\section{Research question and methodology}

The main research question is to explore how PM is incorporated in the functioning of PA in order to contribute to the achievement of developmental goals of the government.

Several questions occur within this frame, e.g.: How to incorporate temporary project organizational structure into permanent (hierarchical) organizational structure that prevails in PA?, How to assure personal responsibility?, Which competences are needed for PM in PA?, How to introduce PM in a rigid environment?, Whose responsibility is this?, How to divide profession from political agenda and assure the continuity of development?, etc.

As all these detailed questions relate to the level of maturity of how PM is incorporated in the functioning of PA system, we would also like to explore the maturity levels of PM in PA that would support the main research question. By doing this, we would like to offer a maturity model for PM in PA that could serve not only for practical illustration in this article but to support the work of other researchers and practitioners in respective area as well.

The methodology used in this article is a combination of (1) literature review, (2) case study of PM in PA of the Republic of Slovenia including analysis of primary and secondary sources on PM deployment in Slovene PA, and (3) development of a maturity model for PM in PA, and its verification on the case of Slovenia.

In defining the PM in the PA maturity model, we started from a question: Which would be the relevant elements to describe the state as well as the development and improvement potential in the respective area? Study of some existing maturity models gave us valuable insight.

The term maturity in project management denotes, according to Kerzner (2001) 'implementation of a standard methodology and accompanying processes' so that a high probability of repeated results exists. The maturity is based on a life-cycle concept, and on a concept of continual improvement as - the higher the maturity stage/ level the better definition and usage of PM tools, techniques, rules and integrative functions. According to the Office of Government Commerce (2006, p. 5), maturity levels 'facilitate organizational transitions from an immature state to become a mature and capable organization with an objective bases for judging quality and solving program and project issues'.

In the following section, we present some PM maturity models that were developed over the past twenty years, and address different areas of relevance. Jain's (1998) maturity model consists of six stages: (1) ad hoc, (2) ritual, (3) compulsive, (4) leader- 
ship, (5) visionary, and (6) passion based. The model is focused on organizations, and explains each maturity level according to 15 attributes/categories. The model is presented in the form of a table, and each cell of the table denotes the development of a PM category that is characteristic and/or required for a certain maturity level or stage.

In the UK, the Office of Government Commerce developed a portfolio, program and project management maturity model (P3M3). The P3M3 model is described by a five-level maturity framework: (1) initial process; (2) repeatable process; (3) defined process; (4) managed process; (5) optimized process, for three entities: project, program, and portfolio (Office of Government Commerce, 2006). For all five levels, key processes are defined, and for each process the following structure is defined: functional achievement/process goals, approach, deployment, review, perception, and performance measures.

Gareis (2003a) developed a project management maturity model in project-oriented organization. The model consists of eight categories: definition of projects and programs, management of projects, management of program, counselling and controlling of projects and programs, project portfolio co-ordination, networking between projects, HRM, and organizational structure in project-oriented organization. Gareis also developed a project management maturity model in a project-oriented society (2003b). This model refers to a broader society such as a state or region. The categories included in the model are: management of projects, management of program, management of project portfolio in project-oriented organizations, HRM in project-oriented organizations, organizational structures in project-oriented organizations, education for PM, research in the PM area, and marketing in the PM area.

Kerzner (2001) defined five levels of project management maturity model (PMMM): common language, common processes, singular methodology, benchmarking, and continuous improvement.

The majority of PM maturity models presented deal with PM at organizational level. None of the presented models answers to our initial research question, however they contribute to understanding the relevance and rationale behind. In our research we focused on a system of PA, and we defined our own model to support our endeavors.

Basic premises for defining the PM maturity level to correspond to PA environment are:

- Central level of observation is a system of PA, not individual PA organizations;

- Inclusion of static and dynamic aspects as well, especially of flexibility for future challenges; and

- Putting the maturity level on the ground of endeavors for constant improvement: from early stages to advanced, and even when reaching the most advanced stage to still have manœuvre for improvement.

The latter is also a reason for naming the model as TPM - Total PM maturity model - to indicate the efforts not only for maturity but for excellence as well: to overcome everything what influences that performance is less than excellent, and establishing 
circumstances needed. The five stages of TPM maturity model are: (1) ad hoc, (2) initiated, (3) implemented, (4) managed, and (5) improved. A description of each maturity stage is provided in Table 1.

\section{PM in Slovene public administration}

PM is in use in Slovene PA since Slovenia became an independent state in 1991. In May 1997, the Government of the Republic of Slovenia adopted the general project management methodology in state administration (MVPDU) (Government of the Republic of Slovenia, 1997), which represented the framework for project planning and implementation in Slovene PA. The MVPDU methodology was developed on the bases of the PRINCE methodology. Although this happened 20 years ago, the MVPDU methodology is still valid and has never been (officially) replaced by a more contemporary one.

We chose Slovenia for a case study as we explored PM in Slovene PA for the past twenty years, and analyzed published documents in this regard. It is not our intention to make Slovenian approach in PA an example (still a long way to go) but to use it to test and validate the proposed TPM model.

\subsection{Deployment of PM in Slovene public administration}

Since its adoption by the government, the MVPDU methodology was first in use especially in the IT-related projects in Slovene PA. Shortly after that, it was used also for other developmental and organizational project. Its usage and deployments has been promptly checked in the years 1999, 2000 and 2002. However, the next (and the last) review of the PM methodology usage in Slovene PA was not performed before 2013. One could expect that meanwhile PM methodology has been spread evenly, and in all segments of PA. However, a current state review in 2013 showed a rather different situation both in respect to usage of PM methodology and to managing projects across the ministries: not all ministries use the PM methodology; only three ministries were able to estimate the number of competent projects leaders according to this methodology; only a few ministries have a project office; not all ministries have defined rules in respect to work on projects. Even where the rules exist, knowledge of this is not common. Significant number of respondents from the ministries where such rules existed answered that they did not have any rule or, that they were not aware of any rules on PM (Žurga, 2013). The analysis of the respondents' comments on strong and weak points of PM in the ministries leads us to a finding that on both sides are the same or similar areas. Therefore, we can conclude that when a certain area is settled/organized it represents a strength, otherwise it is a weakness.

\subsection{Organizational support to PM in Slovene public administration}

The first project office in Slovene PA, to support e-Government program was established at the Government Centre for Informatics in late 1990s. Its tasks were oriented towards administrative support of the program, documentation of meetings, 


\begin{tabular}{|c|c|c|c|c|c|}
\hline & $\begin{array}{c}\text { Ad hoc } \\
\text { (1) }\end{array}$ & $\begin{array}{c}\text { Initiated } \\
(2)\end{array}$ & $\begin{array}{c}\text { Implemented } \\
\text { (3) }\end{array}$ & $\begin{array}{c}\text { Managed } \\
(4)\end{array}$ & $\begin{array}{c}\text { Improved } \\
(5)\end{array}$ \\
\hline $\begin{array}{l}\text { Management } \\
\text { of projects }\end{array}$ & $\begin{array}{l}\text { At some ministries. } \\
\text { PM methodology depends on project } \\
\text { leader. }\end{array}$ & $\begin{array}{l}\text { Ministries introduce own PM methodol- } \\
\text { ogy, and PM rules and processes. }\end{array}$ & $\begin{array}{l}\text { Common PM methodology for PA, im- } \\
\text { plemented throughout whole PA. }\end{array}$ & $\begin{array}{l}\text { PM processes and rules of conduct are } \\
\text { defined and managed for whole PA. } \\
\text { Project organization is incorporated in } \\
\text { PA's permanent organizational structure. }\end{array}$ & $\begin{array}{l}\text { PM processes and rules of conduct are being improved } \\
\text { on on-going bases, for whole PA. } \\
\text { Knowledge and experience from concluded projects is } \\
\text { accumulated and used for further projects, and for im- } \\
\text { proving conditions for their success. }\end{array}$ \\
\hline $\begin{array}{l}\text { Management } \\
\text { of programs } \\
\text { of projects }\end{array}$ & $\begin{array}{l}\text { Ad hoc, pending on the ability of the } \\
\text { project manager to 'sell' importance of } \\
\text { managing the developmental initiative. }\end{array}$ & $\begin{array}{l}\text { A few programs at government lev- } \\
\text { el. Successful implementation of pro- } \\
\text { grams initiate establishing good prac- } \\
\text { tice for others. }\end{array}$ & $\begin{array}{l}\text { Program of projects are regular prac- } \\
\text { tice in PA. Program-related processes } \\
\text { are being implemented. }\end{array}$ & $\begin{array}{l}\text { Program-related processes are fully man- } \\
\text { aged. } \\
\text { Program organization is incorporated in } \\
\text { PA's permanent organizational structure. }\end{array}$ & $\begin{array}{l}\text { PM processes and rules of conduct are being improved } \\
\text { on on-going bases, for whole PA. } \\
\text { Knowledge and experience from concluded programs of } \\
\text { projects is accumulated and used for further programs of } \\
\text { projects, and for improving conditions for their success. }\end{array}$ \\
\hline $\begin{array}{l}\text { Management } \\
\text { of portfolios } \\
\text { of projects }\end{array}$ & $\begin{array}{l}\text { Only at some ministries, based on de- } \\
\text { mand of ministers. }\end{array}$ & $\begin{array}{l}\text { At some ministries. } \\
\text { Need for having project portfolio at gov- } \\
\text { ernment level is articulated, yet still } \\
\text { seeking for political will. }\end{array}$ & $\begin{array}{l}\text { Project portfolio at government level is } \\
\text { implemented, key development proj- } \\
\text { ects are included. } \\
\text { Key criteria for including a project in the } \\
\text { portfolio is political will. }\end{array}$ & $\begin{array}{l}\text { Project portfolio is managed; criteria for } \\
\text { including projects in portfolio at govern- } \\
\text { mental level are defined. The majority of } \\
\text { projects where government is the main } \\
\text { stakeholder is included in the portfolio. }\end{array}$ & $\begin{array}{l}\text { All developmental project of a state that are co-financed } \\
\text { from budget and project leader is appointed by the gov- } \\
\text { ernment are included in the government portfolio. } \\
\text { These projects may be included in different (sub)portfoli- } \\
\text { os, upon defined criteria. }\end{array}$ \\
\hline $\begin{array}{l}\text { Organizational } \\
\text { support for PM }\end{array}$ & $\begin{array}{l}\text { On ad hoc bases. } \\
\text { Projects and project organization are } \\
\text { usually seen as disturbance to regular } \\
\text { ('normal') processes. }\end{array}$ & $\begin{array}{l}\text { At some ministries organizational units } \\
\text { are set, to give support to projects and } \\
\text { to address incorporation of project work } \\
\text { in regular work. They are initiation for } \\
\text { PM offices. }\end{array}$ & $\begin{array}{l}\text { In key ministries, organizational units } \\
\text { are established to support PM at min- } \\
\text { isterial level. } \\
\text { PM office at government level is estab- } \\
\text { lished to address PM at government } \\
\text { level. }\end{array}$ & $\begin{array}{l}\text { Organizational unit(s) (PMO) to support } \\
\text { PM at ministerial and government levels } \\
\text { is (are) established - pending on the na- } \\
\text { tional approach. Basically, two approach- } \\
\text { es are top-down and bottom-up. In re- } \\
\text { spect to this, line of 'command' may differ. }\end{array}$ & $\begin{array}{l}\text { Organizational support to PM (project, program, and } \\
\text { portfolio) is optimized at PA level: one or more PM of- } \\
\text { fices, covering the full range of PM processes. It is con- } \\
\text { stantly being improved in order to stay flexible, operation- } \\
\text { al and a-political. }\end{array}$ \\
\hline HRM for $P M$ & $\begin{array}{l}\text { On ad hoc basis. Focus is on training } \\
\text { in individual ministries and upon inter- } \\
\text { est of public employees or public man- } \\
\text { agers. }\end{array}$ & $\begin{array}{l}\text { More systematic approach to cover } \\
\text { needs in ministries in respect to PM is } \\
\text { initiated. Training programs cover ba- } \\
\text { sic topics. }\end{array}$ & $\begin{array}{l}\text { Competence model for PM and proj- } \\
\text { ect team (PT) members is in place. It is } \\
\text { connected to key HRM processes such } \\
\text { as recruitment, training and remunera- } \\
\text { tion. }\end{array}$ & $\begin{array}{l}\text { Training scheme for PM and PT mem- } \\
\text { bers is in place, supporting the PM com- } \\
\text { petence model. } \\
\text { Focus: competent project managers and } \\
\text { PT members. } \\
\text { PM certification scheme is in place, and is } \\
\text { connected to all HRM processes. }\end{array}$ & $\begin{array}{l}\text { PM competency model and training scheme is being con- } \\
\text { stantly improved, based on: } \\
\text { - Monitoring and analyzing gap between existed PM } \\
\text { competences and those foreseen for the (near) future; } \\
\text { - Including knowledge and experience from finished proj- } \\
\text { ects; and } \\
\text { - Strategic developmental goals of a state. }\end{array}$ \\
\hline $\begin{array}{l}\text { Integration of PM } \\
\text { and strategic } \\
\text { management }\end{array}$ & $\begin{array}{l}\text { No recognized system need, nor ca- } \\
\text { pacity for this, only at some ministries. }\end{array}$ & $\begin{array}{l}\text { Integration is recognized as a mean for } \\
\text { increasing success of strategic plans } \\
\text { implementation. Efforts to increase ca- } \\
\text { pacity are in place. }\end{array}$ & $\begin{array}{l}\text { Rules and legal bases for integration } \\
\text { exist. Processes are formalized. Ac- } \\
\text { ceptance and recognition of benefits is } \\
\text { increased. }\end{array}$ & $\begin{array}{l}\text { Integration is fully managed, and integrat- } \\
\text { ed with budget processes. Focus is on re- } \\
\text { sults oriented budget. Co-ordination of } \\
\text { policies is at high level. }\end{array}$ & $\begin{array}{l}\text { Integration is fully managed. All processes are optimized, } \\
\text { and are being improved. Focus is on realization of state's } \\
\text { vision and long-term developmental goals. }\end{array}$ \\
\hline
\end{tabular}


and formal communication at program leadership level. When the program was concluded the project office was also closed.

In April 2010, the Slovenian government adopted the e-Government Action Plan 2010-2015. To support its implementation, a special organizational structure was established, with a sophisticated decision-making structure trying to connect the leadership of program and of individual projects with the government policies and the government. The political intent somehow disabled this structure to survive when the government changed. In 2013, after some turbulence in political arena new organizational structure to support PM for IT projects was established. So called 'Project co-ordination' was led by a state secretary, and tried to cover what previous organizational structure failed to. Again, the established structure closed with the change of the government.

The government that was appointed in autumn 2014 established the Government Project Office (GPO). GPO deals with those projects that are written in the coalition agreement and exposed as the most important projects of coalition government. The GPO as central unit at the state level provides methodological and system support to ministries that are in charge for government strategic developmental projects (Government of the Republic of Slovenia, 2017).

\subsection{Goals related to $P M$ in $P A$}

In 2015, the Public Administration Development Strategy 2015-2020 was adopted by the Slovenian Government. Two-year action plans for its implementation followed: in April 2015 for the years 2015-2016 (Government of the Republic of Slovenia, 2015b), and in June 2016 for the years 2016-2017 (Government of the Republic of Slovenia, 2016). Goals in respect to PM in Slovene PA are included under operationalization of strategic objectives: efficient organization, project management in public administration. Measures to attain the strategic objectives in respect to PM are (Government of the Republic of Slovenia, 2015a, p. 65):

- Preparation of the PM methodology in PA, including the definition of the reporting system;

- Systematic training of employees in PA on the project-oriented work, through internal training (sharing knowledge within ministries), training at the Administrative Academy and by outsourcers, horizontal transfer of good practice among ministries;

- Establishment of IT supported tool for planning and implementation, monitoring and reporting on major strategic projects; and

- Establishment of the leading body or organizational unit to coordinate and supervise the implementation of projects, and its empowerment from the aspect of competences (e.g. Government Project Office).

In the two-year action plan, concrete targets are defined in respect to the above-mentioned measures (Government of the Republic of Slovenia, 2016). 


\subsection{Maturity level of PM in Slovene PA}

On the basis of the previous presentation, we assessed PM in Slovene PA according to the TPM maturity model. There are at least two ways to present the maturity level achieved, in the form of a table (Figure 1) or as diagram (Figure 2). The latter would be more suitable in case of reference line(s), e.g., for comparison with another country (countries) or with state's targets in respective areas. As in this case, we do not dispose with any reference, therefore the first form (Figure 1) seems to be more appropriate.

\begin{tabular}{|c|c|c|c|c|c|}
\hline & 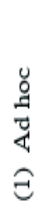 & 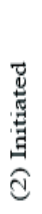 & 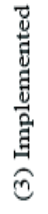 & 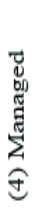 & 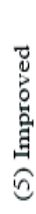 \\
\hline Management of projects & & & & & \\
\hline Management of programs of projects & & & & & \\
\hline Management of portfolios of projects & & & & & \\
\hline Organizational support for PM & & & & & \\
\hline $\mathrm{HRM}$ for $\mathrm{PM}$ & & & & & \\
\hline Integration of $\mathrm{PM}$ and $\mathrm{SM}$ & & & & & \\
\hline
\end{tabular}

Figure 1: PM maturity in Slovene PA (table)

Source: Author

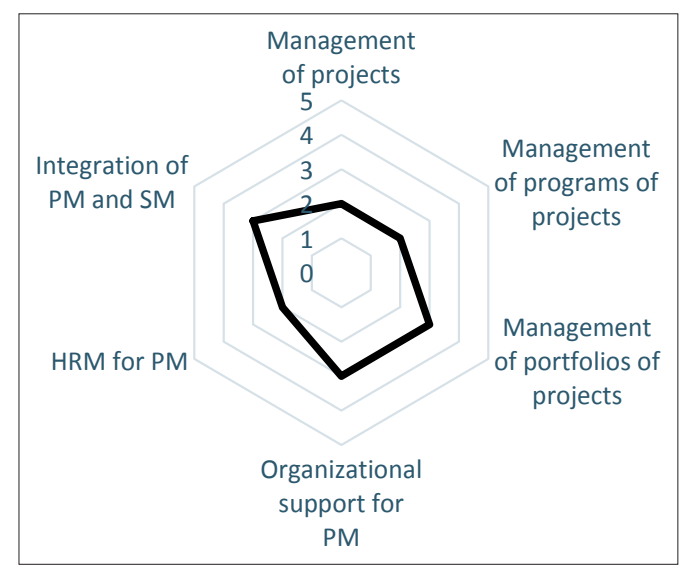

Figure 2: PM maturity in Slovene PA (graph)

Source: Author

The data and evidence that were used for the PM maturity assessment include:

- Analysis of the current state review from 2013 and, presentation of results of the discussions at the strategic workshop performed for high PA employees and other interested parties at the 'Informatics in Public Administration' Conference in December 2013;

- Actual goals of the government in current mandate on project management confirmed in the Coalition Agreement on Co-operation in the Government of the Republic of Slovenia for the mandate period 2014-2018 (Coalition Agreement, 2014);

- Annual ministerial reports for the years 2015 and 2016, and monthly reports of the Government Project Office, all published on the government's webpage; and

- Public Administration Development Strategy 2015-2020, and analysis of two two-year action plans for its implementation, for 2015-2016 and 2016-2017.

More detailed argumentation of the PM maturity in Slovene public administration based on the exposed evidence is provided in the following section.

In respect to Management of projects in Slovene PA we assessed the situation as level (2) - initiated. Although common PM methodology exists, it was adopted already in 1997, and is still valid. We have to be aware of the fact that in these 20 years, circumstances to its usage changed substantially: Slovenia joined the NATO and the EU 
- both have own PM methodology that they reinforce in member states, the first one through following the NATO standards, and the latter through co-financing developmental projects. It is not surprising that the 1997 MVPDU methodology is now (a little bit) old-fashioned, and not adequate any more. Some ministries and PA organizations therefore defined their own PM methodologies and rules of conduct enabling them to manage sectorial projects. It is logical that the lack of an adequate common PM methodology caused a kind of a messy situation: key ministries with their own methodologies, EU funding projects with demands derived from their rules and EC's PM methodology, and inefficient system to address the situation.

In respect to Management of programs of projects in Slovene PA we also assessed the situation as level (2) - initiated. There are some programs of projects that are led at governmental level, however not following the same methodological rule of conduct. Consequently, too much energy goes to (re)inventing structures in program organization to address sectorial co-operation and decision-making levels. We can expose some good practice, however prevailing method still follows 'trial and mistake' principle.

Management of portfolios of projects: here we assess the state as level (3) - implemented. Project portfolio at government level is implemented. The base for including projects in portfolio is the political will; majority of projects were included by coalition agreement, and inclusion of projects that were added later had political consent.

Likewise, Organizational support for PM is assessed as level (3) - implemented. This is basically due to the fact that GPO is established at government level. However, at that stage the GPO cannot be recognized as PM office but more as project office supporting and monitoring only the projects from the government's portfolio.

In respect to HRM for PM the assessed level is (2) - initiated. Training for PM is provided by the Administrative Academy of the ministry of administration. Seminars are performed more on ad hoc interest and not upon adequate developmental plan. Yet, need for leaning training for PM on adequate PM competence model is initiated.

Integration of PM and Strategic Management (SM) is assessed as level (3) - implemented. Rules and legal bases for integration exist and processes are formalized, however the area is not adequately managed yet. As written in the two-year action plan (Government of the Republic of Slovenia, 2016), analysis of needed changes in the area of legal framework for program budget, information solutions and labor organization for institutional units is planned by the end of 2017. This indicates that strengthening integration of PM into strategic management could subsequently follow. We have to be aware that additional development in the area of PM in PA should be assured first, otherwise it cannot move to a higher level.

\section{Discussion}

We already exposed the role of PM in implementing developmental goals of the state, and the importance of its incorporation into strategic management at governmental level. 
Regarding the PM itself, states are not obliged to develop the discipline of PM. However, they do have the opportunity to contribute to the development of the discipline that can - through better performance - improve the society. Through better application of PM in own environment, i.e. in the PA system, governments may contribute to more efficient use of public funds (Barnes, 2003). This is especially important due to the facts that the public sector of each country represents a major share of the GDP, and that states are the biggest employer in the country. State and its apparatus may through the implementation of PM improve its performance, and directly influence a more efficient use of taxpayers' money through implementation of PM principles. Therefore, development of PM competences of public employees - financed by taxpayers' money - is in fact economic for taxpayers: investments into PM are good investments with high returns, i.e. large benefits for society.

Support that governments may offer to the development of discipline of PM includes: fostering education and training for PM in schools and in business environment, promoting professional bodies in establishing or adopting qualifications schemes and accreditations for project managers, entering into contracts only with those performers that have competent project leaders, and demanding professional PM for all projects financed or sponsored by the state. Governments may as well be one of leading actors in the area of PM, or ensure active co-operation in development and maintaining international PM standards. All above mentioned is (or may be) in fact part of a PA system. Of course - situation among countries differ, and this different situation may be assessed also on the bases of a maturity level. For purpose of the research presented in this article, we defined maturity model on PM in PA and named it TPM - Total Project Management maturity model to indicate its intention towards excellent performance.

We assessed PM in Slovene PA upon this model, and we presented the findings in Figures 1 and 2. Here, we discuss assessment as well prevailing reasons for it. As it can be seen from the assessment, the maturity level of PM in Slovene PA is somewhere 'in between'. However, as areas included in the TPM model are very much connected we have to be aware that additional development in the area of PM in PA should be assured first otherwise the system of PA cannot move to a higher level. This is especially evident when we analyze how PM and SM are integrated in order to support the realization of national strategic goals.

This leads us to discussion on maturity model itself. On the case of Slovenia we can see that the picture (Figure 1) is quite in balance. Majority of maturity model's elements are in the 'middle' or very close to that. It would be unrealistic to have major differences in assessments of individual categories of the TPM maturity model, and we could even indicate system error what is not the case. This means that description of each maturity level higher as the current one represents a desired state for the future. Furthermore, it indicates what has to be achieved on higher level of maturity, and plans can be elaborated accordingly. 
Part of this discussion goes also to clarification how to make maturity assessments. Is it necessary to base on some questionnaires among ministries and other PA organizations? Majority of PM maturity models that we mentioned in our review consider the maturity at organizational level. They indeed lean on questionnaires for relevant employees, especially project managers, project teams' members and leadership. However, in the TPM maturity model we have to be aware that the central level of observation is a system of PA and not individual PA organizations. Consequently, as (public) management in PA is at system level covered by ministry in charge of administration and ministry of finance - assessment may start here. Upon the first current state analysis, effort for facts gathering will then be directed accordingly. If the first assessment of individual maturity model element is (4) - managed or even (5) - improved, then clear evidence of the process has to exist. If not, the first assessment was too optimistic.

\section{Main findings and conclusions}

A basic finding in respect to maturity level of PM in Slovene PA is that prevailing maturity level is (3) - implemented and some elements are close to it, at the level (2) - initiated. This is rather low especially if we know that the state benefits from the EU funds, and is therefore interested to have an efficient support system for its developmental projects. However, the analysis of PM in Slovene PA in 2013 clearly showed that since the research in 2002 the situation in Slovene public administration in respect to PM has not changed significantly although the requirements as well as the number of projects have changed substantially. The main areas for further consideration in respect to PM in Slovene PA are:

1. Incorporation of PM in the general management of administrative organizations. Special attention needs to be given to the incorporation of project organizational structure - as temporary organizational structure - into formal organizational structure of administrative organization - as permanent organizational structure - as well as to responsibility problems;

2. Integration of SM and PM for realization of goals, allocation of resources and performance management, at organizational as well at system level;

3. Establishing of sound grounds for integration of SM and PM. This demands also appropriate training - not only for PM - and more deliberate efforts for PM methodology implementation; and

4. Further development of PM methodology and development of PM tools as a means for PM operationalization, establishing integrative functions of PM, and change of attitudes towards PM in administration. Work on projects has to become a common working method, and not a particularity that somehow varies from basic work tasks.

What the case presented clearly shows that all of the above-mentioned areas of consideration existed 10-15 years ago (Žurga, 2004). Yet, since then the level of complexity increased substantially. What is needed for a state is a planned and consistent 
approach to PM that will support the implementation of developmental goals of a state efficiently and consistently, and together with other aspects of functions will contribute to good public governance.

The TPM maturity model that we developed as a methodological tool to assess the maturity of PM in Slovene PA proved to be an appropriate and valuable tool. Moreover, as it addresses areas that are important for PM and are also a part of a broader picture of public management it may be used as a tool to identify the gap between current and 'ideal' situation.

In our consideration of PM in PA we oriented to the aspect of PM performance, and not performance of individual projects or programs. The latter we assume to be a part of the PM processes at the system level, and related decision-making. However, it could be interesting to upgrade the offered TPM maturity model with this aspect, namely with (precise, or ground) methodology in this respect.

As areas for further research and investigation, we can propose a few: operationalization of the TPM maturity level with support and detailed methodology development, comparing maturity of PM in PAs of different countries, e.g. among the EU member states, between some neighboring countries or comparison between two or more countries upon relevant criteria. Another possibility is to capture good practice of those countries that do achieve maturity level (5) - improved, or to make a comparison between such countries, analyze the circumstances that contribute to the PM in PA system, or to identify different ways leading to the same maturity level - countries' stories.

\section{References:}

1. Barnes, M., 'Government and Project Management', in Voropaev, V. (ed.), Project Oriented Business and Society, Moscow: IPMA - SOVNET, 2003, pp. 1-4.

2. Collins, P., 'The Vicissitudes of Change: Public Policy Sidelines. Public Administration - the 1980s', in Dwivedi, O.P. (ed.), Public Administration in a Global Context: IASIA at 50, Brussels: Bruylant, 2011, pp. 75-97.

3. Dwivedi, O.P. and William, G., 'Public Administration and IASIA: Promoting Administrative Excellence Globally', in Dwivedi, O.P. (ed.), Public Administration in a Global Context: IASIA at 50, Brussels: Bruylant, 2011, pp. 21-52.

4. European Commission, EuropeAid Cooperation Office, 'Project Cycle Management Guidelines', Brussells, 2004, [Online] available at https://ec.europa.eu/europeaid/aiddelivery-methods-project-cycle-management-guidelines-vol-1_en, accessed on January 7, 2017.

5. Ferlie, E., Ashburner, L., Fitzgerald, L. and Pettigrew, A., The New Public Management in Action, Oxford: Oxford University Press, 1996.

6. Flynn, N. and Strehl, F., Public Sector Management in Europe, Hemel Hempstead: Prentice Hall, 1996.

7. Gareis, R., 'Competencies in the Project-Oriented Organization', in Voropaev, V. (ed.), Project Oriented Business and Society, Moscow: IPMA - SOVNET, 2003a, pp. 1-8.

8. Gareis, R., 'Management in the Project-Oriented Society', in Voropaev, V. (ed.), Project Oriented Business and Society, Moscow: IPMA - SOVNET, 2003b, pp. 1-13. 
9. Government of the Republic of Slovenia, Project Office of the Government of the Republic of Slovenia, 2017, [Online] available at http://www.vlada.si/teme_in_projekti/ projektna_pisarna/, accessed on January 7, 2017.

10. Government of the Republic of Slovenia, Ministry of Public Administration, 'Dveletni akcijski načrt izvedbe strategije razvoja javne uprave 2015-2020 za leti 2016 in 2017' (Two-year Action Plan for the Implementation of the 2015-2020 Public Administration Development Strategy for the Period 2016-2017), 2016, [Online] available at http:// www.mju.gov.si/fileadmin/mju.gov.si/pageuploads/SOJ/STRATEGIJA_JU2020_IN_ AKCIJSKI_PLAN/Dvoletni_akcijski_nacrt_SJU_16-17.pdf, accessed on January 7, 2017.

11. Government of the Republic of Slovenia, Ministry of Public Administration, 'Public Administration 2020: Public Administration Development Strategy 2015-2020', 2015a, [Online] available at http://www.mju.gov.si/fileadmin/mju.gov.si/pageuploads/JAV NA_UPRAVA/Kakovost/Strategija_razvoja_ANG_final_web.pdf, accessed on January 7, 2017.

12. Government of the Republic of Slovenia, Ministry of Public Administration, 'Two-year Action Plan for the Implementation of the 2015-2020 Public administration Development Strategy for the Period 2015-2016', 2015b, [Online] available at http://www.mju. gov.si/si/delovna_podrocja/razvoj_projektov_kakovost_javne_uprave_in_kohezijska_ politika/strategija_razvoja_javne_uprave/, accessed on January 7, 2017.

13. Government of the Republic of Slovenia, 'Splošna metodologija vodenja projektov v slovenski državni upravi, priročnik' (General Project Management Methodology in State Administration Handbook), Ljubljana: Government Centre for Informatics, 1997.

14. Hammerschmid, G., Van de Walle, S., Andrews, R. and Bezes, P., Public Administration Reforms in Europe: The View from the Top, Northampton, MA: Edward Elgar Publishing, 2016.

15. Jain, A., 'Project Management Maturity Model - A New Outlook', in Hauc, A., Kovač, J., Rozman, R., Semolič, B. and Škarabot, A. (eds.), Proceeding of the 14th World Congress on Project Management, Ljubljana, Slovenia: ZPM, 1998, pp. 223-229.

16. Kerzner, H., Strategic Planning for Project Management Using a Project Management Maturity Model, New York: John Wiley \& Sons, 2001.

17. Coalition Agreement, Koalicijski sporazum o sodelovanju v Vladi Republike Slovenije za mandatno obdobje 2014-2018 (Coalition Agreement on Co-operation in the Government of the Republic of Slovenia for the Mandate Period 2014-2018), 2014, [Online] available at http://www.vlada.si/fileadmin/dokumenti/si/dokumenti/2014_Koalicijski_ sporazum_parafiran.pdf, pp. 1-72, accessed on January 7, 2017.

18. Kostalova, J., Tetrevova, L. and Patak, M., 'The System of Support for Projects Co-Financed by EU Funds in the Czech Republic', 2015, Transylvanian Review of Administrative Sciences, vol. 45E, pp. 97-115.

19. Nicolaides, P., 'Preparing for EU Membership: The Paradox of Doing What the EU Does Not Require You to Do', 2003, Eipascope, vol. 2, pp. 11-17.

20. Office of Government Commerce, Portfolio, Programme \& Project Management Maturity Model (P3M3), version 1.0, London, 2006.

21. Osborne, D. and Gaebler, T., Reinventing Government: How the Entrepreneurial Spirit is Transforming the Public Sector, Reading, MA: Addison-Wesley Publishing Company, 1992. 
22. Powell, M.D. and De Vries, M.S., 'The Pragmatic Institutionalism: NPM', in Dwivedi, O.P. (ed.), Public Administration in a Global Context: IASIA at 50, Brussels: Bruylant, 2011, pp. 99-128.

23. Rozman, R., 'Uresničevanje strategij s projektno organizacijo' (Strategies Implementation through Project Organization), 2000, Projektna mreža Slovenije, no. 1, pp. 5-12.

24. Youker, R., 'Managing the Project Cycle for Time, Cost and Quality: Lessons from World Bank Experience', 1989, International Journal of Project Management, vol. 7, no. 1, pp. 52-57.

25. Young, R., Young, M., Jordan, E. and O'Connor, P., 'Is Strategy Being Implemented through Projects? Contrary Evidence from a Leader in New Public Management', 2012, International Journal of Project Management, vol. 30, no. 8, pp. 887-900.

26. Žurga, G., 'Projektni menedžment za podporo učinkovitega doseganja razvojnih ciljev državne informatike' (Project Management for Efficient Realization of Developmental Goals of State's Informatics), in Schlamberger, N., Kričej, D., Fileš, N., Bucik, A., Skukan, K., Turković, D. and Golob, J. (eds.), Informatika v javni upravi (Informatics in Public Administration), Ljubljana: Slovensko društvo Informatika, 2013, pp. 1-4.

27. Žurga, G., Projektni menedžment kot del menedžmenta v javni upravi (Project Management as a Part of Public Management), Ljubljana: Fakulteta za družbene vede, 2004. 